\title{
ESTUDO DA FORMAÇÃO E REDUÇÃO DA FERRITA DE ZINCO CONTIDAS NOS PÓS DE ACIARIA ELÉTRICA USANDO MISTURAS $\mathrm{CO}-\mathrm{CO}_{2}{ }^{*}$
}

\author{
Mery-Cecilia Gómez-Marroquín ${ }^{1}$ \\ José Carlos D'Abreu \\ Hélio Marques Kohler ${ }^{3}$ \\ Raimundo Nonato Rodrigues Filho ${ }^{4}$
}

\section{Resumo}

O presente trabalho trata da formação da ferrita de zinco a partir da mistura e posterior reação solido-solido entre o óxido de zinco e óxido de ferro - $\mathrm{Fe}_{2} \mathrm{O}_{3}$ puros em proporções equimolares. A faixa de temperatura onde teve lugar a formação foi entre 1073 e $1373 \mathrm{~K}$. Testes de redução da ferrita de zinco sintética-ZF e pós de aciaria elétrica-EAFD foram realizadas usando misturas de $\mathrm{CO}$ e $\mathrm{CO}_{2}$ que variaram entre 50 e 100\% CO. Ambos os testes (formação e redução de ZF e EAFD) foram suportados usando técnicas de caracterização física, química, estrutural e microscópica. No caso da redução, foi observado que tanto a temperatura como a percentagem de $\mathrm{CO}$, foram os fatores que, mais afetaram a redução de ferrita de zinco contida no EAFD. A máxima percentagem de redução foi $85 \%$, para $100 \% \mathrm{CO}$, $1373 \mathrm{~K}$ e $105 \mathrm{~min}$, e $52 \%$, para $50 \%$ CO, $1373 \mathrm{~K}$ e $105 \mathrm{~min}$. Por outro lado, atingiu o $100 \%$ para $100 \% \mathrm{CO}, 1273 \mathrm{~K}$, em $80.75 \mathrm{~min}, 60 \%$, para $50 \%$ CO a $1373 \mathrm{~K}$ durante 105 min.

Palavras-chave: Redução; Pós de aciaria elétrica; Ferrita de zinco.

\section{STUDY OF FORMATION AND REDUCTION OF ZINC FERRITE CONTAINED ELECTRIC ARC FURNACE DUSTS BY CO - $\mathrm{CO}_{2}$ GAS MIXTURES}

\section{Abstract}

The present work deals about the zinc ferrite synthesis, occurred through a solidsolid reaction in a selected range of temperatures, using as reactant an equimolar mixture of pure iron oxide- $\mathrm{Fe}_{2} \mathrm{O}_{3}$ and pure zinc oxide - $\mathrm{ZnO}$. The range temperature of formation was of 1073 to $1373 \mathrm{~K}$. After that, took place the reduction of equimolar synthetic zinc ferrite-ZF and Electric Arc Furnace Dusts-EAFD by gas mixtures CO $\mathrm{CO}_{2}$, from $50 \%$ and $100 \%$ of $\mathrm{CO}$. Both testes (formation and reduction) were supported by physical, chemical, structural and microscopic characterizations of both, initial zinc ferrite generated in laboratory and the remained after reaction. It was observed that the temperature and $\mathrm{CO}$ content were the main factors affecting the zinc ferrite reduction. The maximum reductions of ZF indexes obtained in these experiments were $85 \%$, for $100 \% \mathrm{CO}$ at $1373 \mathrm{~K}$, in $105 \mathrm{~min}$, and $52 \%$, for $50 \% \mathrm{CO}$ at $1373 \mathrm{~K}$, elapsed $105 \mathrm{~min}$ and $100 \%$, for $100 \% \mathrm{CO}$ at $1273 \mathrm{~K}$, in $80.75 \mathrm{~min}$, and $60 \%$, for $50 \% \mathrm{CO}$ at $1373 \mathrm{~K}$ during 105 minutes.

Keywords: Reduction; EAFD; Zinc ferrite.

1 DSc, Metallurgical Engineer, IGI-UNI/APMMM researcher and DEMa, PUC-Rio, Ironmaking Group researcher, Lima-Perú \& RJ, Brasil respectively.

2 Emeritus Professor, DSc, Metallurgical Engineer, DEMa / PUC-Rio Ironmaking Group Coordinator RJ, Brasil.

PhD, Metallurgical Engineer, DEMa, PUC-Rio, Ironmaking Group researcher, RJ, Brasil.

M Sc, Metallurgical Engineer, DEMa, PUC-Rio, Ironmaking Group researcher, RJ, Brasil. 


\section{INTRODUCTION}

Several residues generated in the reduction and refining sectors of a steelwork plant, bears expressive quantities of zinc in their compositions, mainly in the form of oxide and ferrite compounds. Nowadays, these particulates, regarded as ambientally deleterious materials, are being the main focus of several stocking procedures and studies to reclaim its zinc content. Further, the zinc content in these residues could be as high as $25 \%$ to $40 \%$ of their composition, being commonly distributed as $70 \%$ in the form of zinc ferrite -ZF and the rest as zinc oxide and metallic one (minor part) [1]. Moreover, its quantity increases the particulates content in the generated fumes, as the recycling of galvanized steel scrap increases as burden in the steelmaking processes. Therefore, the presence of zinc ferrite in steelmaking dusts is a hard reality, and, on top of that the reduction of this substance is still not well understood. According to Jyh-Jen [2] et al., in the temperature range of 1073 to $1473 \mathrm{~K}$ the carbothermic reduction of zinc ferrite has an apparent activation energy of circa $92.91 \mathrm{~kJ} / \mathrm{mol}$. They also proposed a reduction phenomenology involving basically two steps: firstly, the initial decomposition of zinc ferrite, $\mathrm{ZnFe}_{2} \mathrm{O}_{4}$, to $\mathrm{ZnO}$ and $\mathrm{Fe}_{2} \mathrm{O}_{3}$, and secondly, a simultaneous and competitive final reduction of these oxides. Additionally, depending on the reduction temperature, their proposal is that the metallic zinc released should evolve as vapor, generating a degree of porosity in the solid which increases the specific surface area of the remained reacting material and consequently, its volume. This increase in volume, accompanying the reduction of the iron oxides in the final stage of the process, should also be followed by the iron sinterization, thus producing a decreasing of the pores diameter and the particles volume.

This work is a part of a broader project which major purpose is to establish a complete kinetic and morphological phenomenology, aiming a better understanding of the reduction process of the zinc ferrite present in the steelmaking dusts by gaseous mixtures of $\mathrm{CO}$ and $\mathrm{CO}_{2}$.

\section{METHODOLOGY}

Inicially, synthetic zinc ferrite samples were made in laboratory from $\mathrm{Fe}_{2} \mathrm{O}_{3} / \mathrm{ZnO}: 1 / 1$ mixtures following the technique developed by Hsi-Kuei Chen; Ching-Yi Yang [1] Bid S.; Pradhan S.K. [3] and Gómez-Marroquín M.C.; D’Abreu J.C. [4-9]. In continuing it was agglomerated into the shape of cylindrical briquettes according to Hui-Ning Zhang [10].

Firstly, the zinc ferrite and the Electric Arc Furnace Dusts-EAFD were structurally characterized through X-Ray diffraction, using a difractometer Siemens, model D5000 and the following operational conditions: I=30 A, V=40 kV and copper anode $(\lambda=1,5406 \AA$, CuK $-\alpha)$. The analytical software applied was the Diffract Plus, Topas, version 2.1 from Bruker AXS for quantitative analysis by the Rietveld method.

The samples of zinc ferrite and the Electric Arc Furnace Dusts-EAFD were also characterized morphologically using a Scan Electron Microscope - SEM (DSM 960 Zeiss West Germany, V = $20 \mathrm{kV}$ ) and a Transmission Electron Microscope - TEM ( Model JEOL $2010 \mathrm{~V}=200 \mathrm{kV}$ ).

The physical characterization of the zinc ferrite was made employing:

- A Multipycnometer quanta chrome $V=120 \mathrm{~V}$ and $P=18 p s i$, for the density measurements; 
- A Mastersize $\mu$, Version 2.12 from Malvern Instruments, for the average size distribution and specific surface area determination.

After those essays, portions of zinc ferrite and the Electric Arc Furnace Dusts-EAFD powder weighting $7 \mathrm{~g}$ were agglomerated in cylindrical briquettes with a diameter of $2.54 \mathrm{~cm}$.

The reduction runs were performed in a tubular electric furnace, linked to a gas line with mixtures of $\mathrm{CO}, \mathrm{CO}_{2}$ and $\mathrm{N}_{2}$. The experiment temperatures were 1073, 1173, 1223,1273 and $1373 \mathrm{~K}$ and the reaction times $8,32.25,56.5,80.75$ and 105 minutes. The gaseous compositions utilized were $100 \% \mathrm{CO}$ and $50 \% \mathrm{CO}-50 \% \mathrm{CO}_{2}$.

\section{RESULTS AND DISCUSSION}

\subsection{Structural Characterization}

In Figure 1 (a) Rietveld adjusted diffractogram of a zinc ferrite synthetic sample is presented, showing the phases and their corresponding percentages: zinc ferrite $\left(\mathrm{ZnFe}_{2} \mathrm{O}_{4}\right)-94.82 \%$, Iron (III) Oxide $\left(\mathrm{Fe}_{2} \mathrm{O}_{3}\right)-3.48 \%$, Zinc Oxide $(\mathrm{ZnO})-1.70 \%$ and (b) Rietveld adjusted diffractogram of a EAFD sample is showed with: zinc ferrite $\left(\mathrm{ZnFe}_{2} \mathrm{O}_{4}\right)-30.82 \%$, Iron (III) Oxide $\left(\mathrm{Fe}_{2} \mathrm{O}_{3}\right)-61.23 \%$, Zinc Oxide $(\mathrm{ZnO})-7.95 \%$.

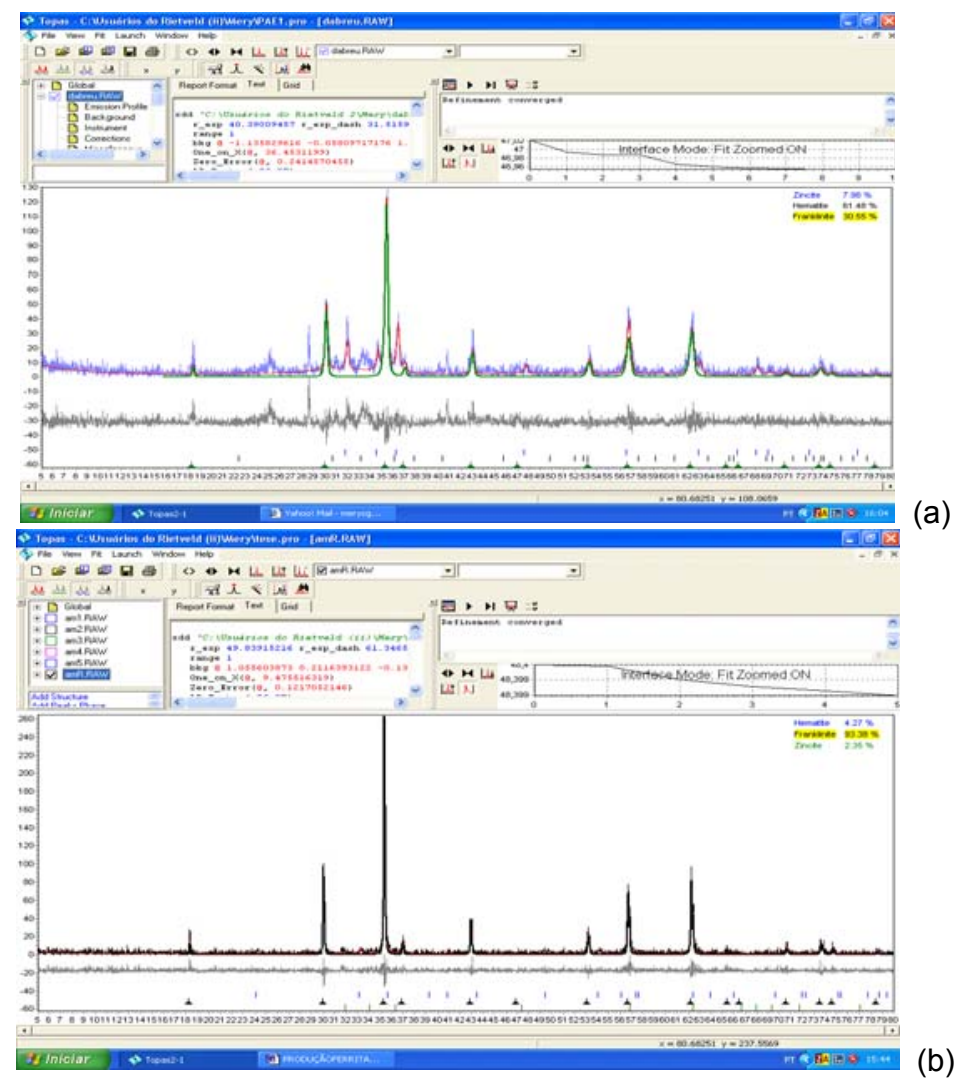

Figure 1. Adjustment by Rietveld's method of XRD patterns of (a) zinc ferrite synthetic-ZF; and (b) EAFD.

\subsection{Chemical Characterization}

Samples of EAFD generated in a Brazilian mini-mill steelwork were chemical characterized in situ using Absorption Atomic Equipment. In Table 1 the EAFD's chemical composition by compounds and elements are observed. 
Table 1. EAFD's chemical composition by compounds and elements

\begin{tabular}{|c|c|c|c|c|c|c|c|c|c|c|c|c|c|c|}
\hline $\mathrm{SiO}_{2}$ & $\mathrm{MnO}$ & $\mathrm{P}_{2} \mathrm{O}_{5}$ & $\mathrm{Cr}_{2} \mathrm{O}_{3}$ & $\mathrm{Na}_{2} \mathrm{O}$ & $\mathrm{K}_{2} \mathrm{O}$ & $" \mathrm{Fe}_{2} \mathrm{O}_{3}$ " & $\mathrm{MgO}$ & $\mathrm{CaO}$ & $\begin{array}{l}\text { "ZnFe } 2 \mathrm{O}_{4} " \\
+ \text { " } \mathrm{ZnO} "\end{array}$ & $\mathrm{CdO}$ & $\mathrm{PbO}$ & $\mathrm{Al}_{2} \mathrm{O}_{3}$ & C & $S$ \\
\hline 2,81 & 1,87 & 0,28 & 0,40 & 3,77 & 3,85 & & 1,1 & $1, \mathrm{~s}$ & 28,00 & 0,06 & 0 & 0,57 & 1,38 & 0,73 \\
\hline $\mathrm{Fe}$ & $\mathrm{Zn}$ & Si & $\mathrm{Mn}$ & $P$ & $\mathrm{Cr}$ & $\mathrm{N}$ & $\mathrm{K}$ & $\mathrm{Mg}$ & $\mathrm{Ca}$ & $\mathrm{Cd}$ & $\mathrm{Pb}$ & $\mathrm{Al}$ & C & S \\
\hline 44,92 & 11,79 & 1,31 & 1,45 & 0,06 & 0,14 & 1,40 & 1,60 & 0,72 & 1,42 & 0,05 & 2,32 & 0,15 & 1,48 & 0,81 \\
\hline
\end{tabular}

\subsection{Microscopic Characterization}

Completing the identification and characterization of the phases present in the zinc ferrite samples, the SEM and TEM analysis were made.

In Figure 2 (a) SEM image of the zinc ferrite, as produced in the laboratory, is presented. In it is clear the major presence of zinc ferrite white globular, besides of some pores and (b) Scanning electron microscopy (SEM) with X-ray energy dispersive spectrometry (EDS) was performed to gain further knowledge of the EAFD particles structure, morphology and their chemical composition. The same samples were also subjected to the element distribution analysis $(\mathrm{O}, \mathrm{Fe}, \mathrm{Zn}, \mathrm{Mg}, \mathrm{Ca}, \mathrm{Cr}, \mathrm{Si}$, $\mathrm{Mn}$ ) through X-ray mapping analysis via SEM. As for the TEM image, in Figure 3, one can observe the presence of tiny zinc ferrite particles having sizes on the range of 100 to $200 \mathrm{~nm}$.

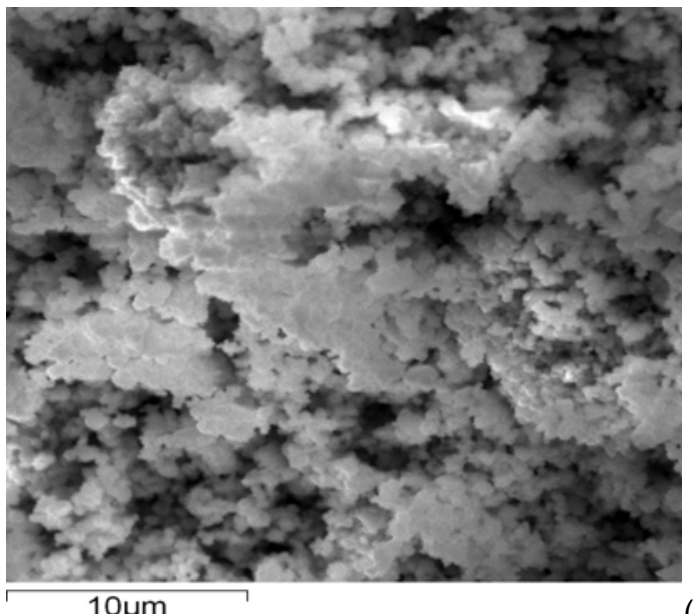

$10 \mu \mathrm{m}$ (a)

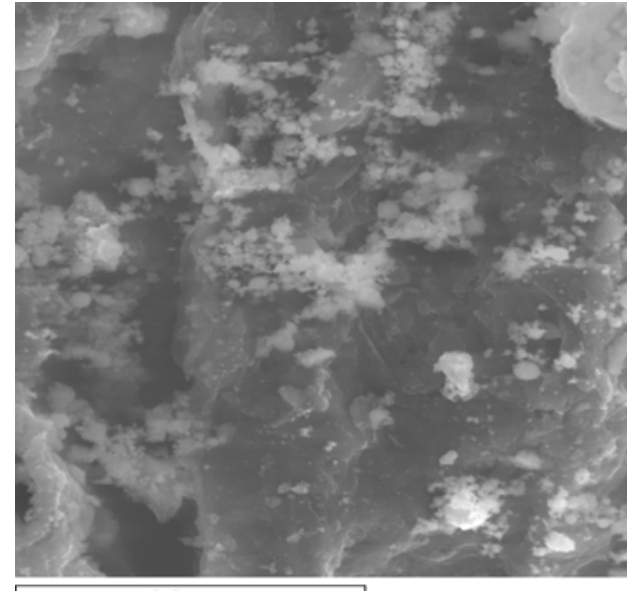

$20 \mu \mathrm{m}$ (b)

Figure 2. SEM image of typical structures of (a) produced equimolar zinc ferrite-ZF and (b) EAFD.

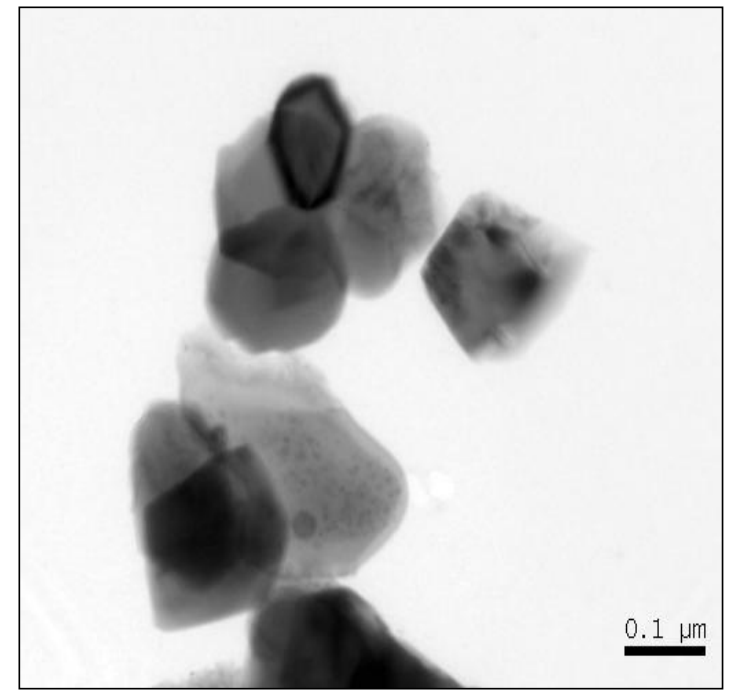

Figure 3.TEM image of typical structures of produced equimolar zinc ferrite-ZF. 


\subsection{Physical Characterization}

In this aspect the samples particles of zinc ferrite-ZF and the Electric Arc Furnace Dusts-EAFD average size, specific surface area, density and porosity were measured. The results were showed in the Table 2:

Table 2. Physical characterization data of ZF and EAFD.

\begin{tabular}{lrrr}
\hline \multicolumn{1}{c}{ SAMPLES } & ZF & \multicolumn{2}{c}{ EAFD } \\
\hline Particle (clusters) & 3.95 & 1.58 \\
average diameter, $\mu \mathrm{m}$ & 38.23 & 54.49 \\
$\begin{array}{l}\text { Specific surface area, } \\
\mathrm{m}^{2} / \mathrm{g}\end{array}$ & & \\
$\begin{array}{l}\text { Density, } \mathrm{g} / \mathrm{cm}^{3} \\
\text { Sample's briquette }\end{array}$ & 5.71 & 5.42 \\
porosity & 0.45 & 0.44 \\
\hline
\end{tabular}

One must observe that the density and the sample's briquette porosity were significantly similar to the one presented in the Tong, Lee Fui [11] work (being the theoretical zinc ferrite density is circa $5.34 \mathrm{~g} / \mathrm{cm}^{3}$ ).

\subsection{Reduction}

The gas compositions and temperatures, elected for the tests, were chosen taking into account the phase predominance operational diagram - PPOD for the $\mathrm{Zn}-\mathrm{Fe}-\mathrm{C}$ O system, determined by the authors [11].

In Figure 4 the PPOD for $\mathrm{Zn}-\mathrm{Fe}-\mathrm{C}-\mathrm{O}$ is depicted. In it the equilibria $\mathrm{ZnO}-\mathrm{Zn}$ and $\mathrm{Fe}_{2} \mathrm{O}_{3}-\mathrm{Fe}_{3} \mathrm{O}_{4}-\mathrm{FeO}-\mathrm{Fe}$, with a $\mathrm{CO}-\mathrm{CO}_{2}$ atmosphere, and the predominance area for various species, are signaled. The reduction mechanism was the reaction occurring via gaseous intermediates (equimolar zinc ferrite reduction by $\mathrm{CO}$ together with the Boudouard reaction):

- Indirect reductions by $\mathrm{CO}$ :

$$
\begin{aligned}
& 3\left(\mathrm{ZnO} \cdot \mathrm{Fe}_{2} \mathrm{O}_{3}\right)(\mathrm{s})+\mathrm{CO}(\mathrm{g})=(\mathrm{ZnO})_{3}\left(\mathrm{Fe}_{3} \mathrm{O}_{4}\right)_{2}(\mathrm{~s})+\mathrm{CO}_{2}(\mathrm{~g}) \\
& (\mathrm{ZnO})_{3}\left(\mathrm{Fe}_{3} \mathrm{O}_{4}\right)_{2}(\mathrm{~s})+2 \mathrm{CO}(\mathrm{g})=(\mathrm{ZnO})_{3}(\mathrm{FeO})_{6}(\mathrm{~s})+2 \mathrm{CO}_{2}(\mathrm{~g}) \\
& (\mathrm{ZnO})_{3}(\mathrm{FeO})_{6}(\mathrm{~s})+9 \mathrm{CO}(\mathrm{g})=3 \mathrm{Zn}(\mathrm{g})+6 \mathrm{Fe}(\mathrm{s})+9 \mathrm{CO}_{2}(\mathrm{~g})
\end{aligned}
$$

- Global indirect reduction:

$$
\mathrm{ZnO} . \mathrm{Fe}_{2} \mathrm{O}_{3(\mathrm{~s})}+4 \mathrm{CO}_{(\mathrm{g})}=\mathrm{Zn}_{(\mathrm{g})}+2 \mathrm{Fe}_{(\mathrm{s})}+4 \mathrm{CO}_{2(\mathrm{~g})}
$$

- Boudouard reaction

$$
\mathrm{CO}_{2(\mathrm{~g})}+\mathrm{C}_{(\mathrm{s})}=2 \mathrm{CO}_{(\mathrm{g})}
$$




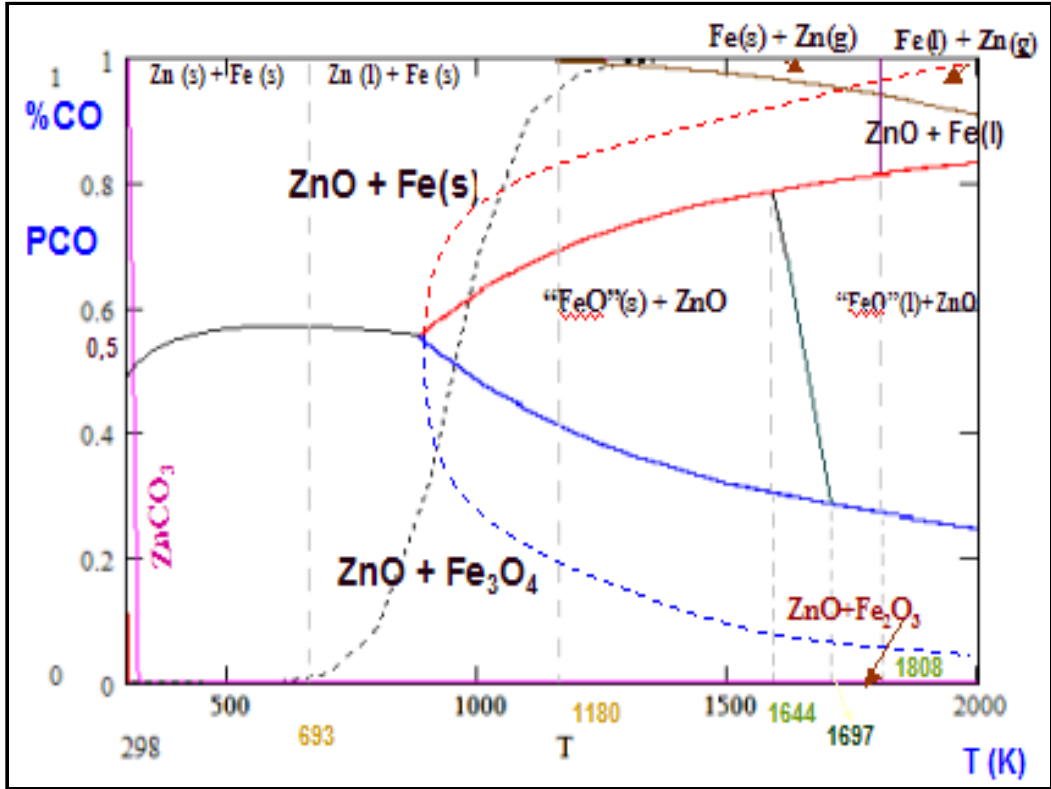

Figure 4. Phase predominance operational diagram - PPOD, for the Zn-Fe-C-O system.

The obtained kinetic curves for the zinc ferrite reduction, for different temperatures, are presented in Figure $5\left(50 \% \mathrm{CO}-50 \% \mathrm{CO}_{2}\right.$ mixtures) and in Figure $6(100 \% \mathrm{CO})$.

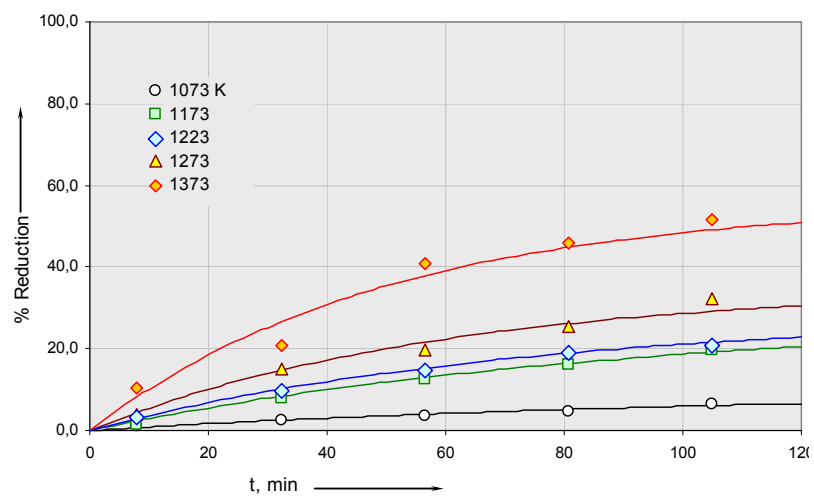

(a)

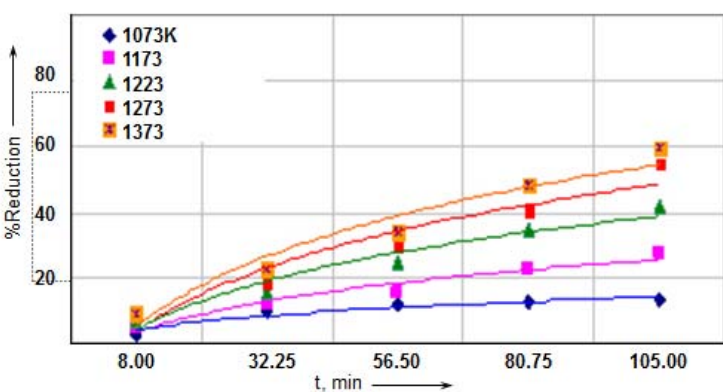

(b)

Figure 5. Reduction by $50 \% \mathrm{CO}-50 \% \mathrm{CO}_{2}$ gas mixtures at different temperatures of (a) ZF and (b) EAFD.

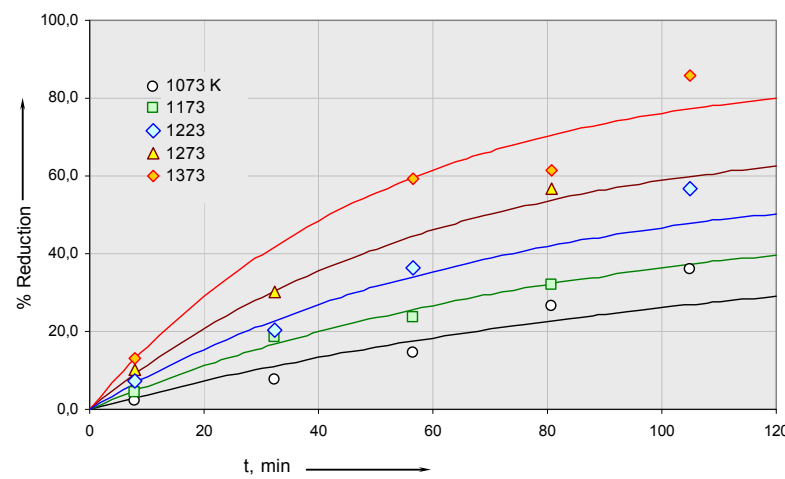

(a)

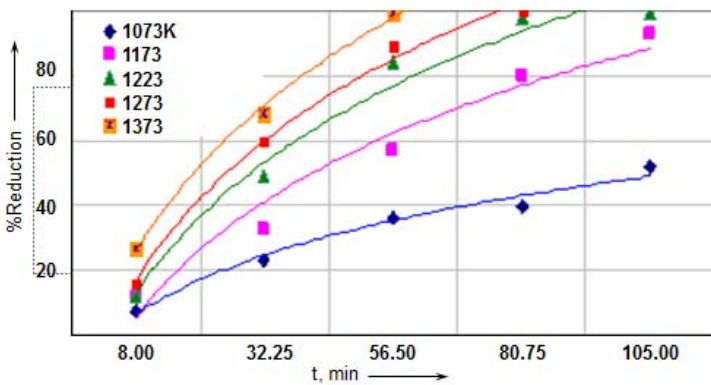

(b)

Figure 6. Reduction by $100 \% \mathrm{CO}$ gas mixtures at different temperatures of (a) ZF and (b) EAFD. 
The maximum zinc ferrite synthetic reductions indexes obtained in these experiments were $85 \%$, for $100 \% \mathrm{CO}$ at $1373 \mathrm{~K}$, in $105 \mathrm{~min}$, and $52 \%$, for $50 \% \mathrm{CO}$ at $1373 \mathrm{~K}$, and $100 \%$, for $100 \%$ CO at $1373 \mathrm{~K}$, in $105 \mathrm{~min}$, and approximately $60 \%$, for $50 \% \mathrm{CO}$ at $1373 \mathrm{~K}$ elapsed $105 \mathrm{~min}$, in the case of EAFD reduction. According to the information of Figure 6 , it is notably that maximum reduction percentage that was achieved by EAFD's reduction through CO pure was of circa of $100 \%$ at $1273 \mathrm{~K}$ during a heating time of 80.75 minutes.

Another hand, Random Nucleation Reaction Model: $k t=-\ln \left(1-\alpha^{\prime}\right)$; where the $\alpha$ is the fractional conversion, $k$ is the specify rate constant and $t$ is the heating time; was used in order to fit the experimental fractional conversions (reduction percentage) and so was estimated the values of Apparent Activation Energy-Ea and maximum reduction of ZF and EAFD respectively. This data is showed in Table 3.

Table 3. Kinetic data and maximum reduction of ZF and EAFD

\begin{tabular}{lllll}
\hline \multirow{2}{*}{ Samples } & \multicolumn{2}{c}{$50 \% \mathrm{CO}-50 \% \mathrm{CO}_{2}$} & \multicolumn{2}{c}{$100 \% \mathrm{CO}$} \\
& Ea, kJ.mol ${ }^{-1}$ & $\%$ Red. Max. & Ea, kJ.mol ${ }^{-1}$ & $\%$ Red. Max. \\
\hline ZF & 91.71 & 52 & 55.60 & 85 \\
EAFD & 100.51 & 60 & 54.74 & 100 \\
\hline
\end{tabular}

The observed differences between the Activation Energy values, hints changing in overall reaction mechanism toward a less temperature sensitive process.

\section{CONCLUSIONS}

$\checkmark$ The phase predominance operational diagram - PPOD, furnished the key information for temperatures and \% $\mathrm{CO}$ values utilized in the reducing kinetic experiments;

$\checkmark$ The microscopic characterization of the zinc ferrite powders, permitted the observation of clusters formed by the individual particles, which had the average size ranging from 100 to $200 \mathrm{~nm}$;

$\checkmark$ The physical characterization in order to determinate the density and the sample's briquette porosity of ZF and EAFD showed values significantly similar.

$\checkmark$ From the ZF and EAFD and gaseous CO mixtures reducing curves, the following conclusions are drawn:

a. Increases in temperatures, reaction time and $\mathrm{CO}$ percentage produced, as expected, higher zinc ferrite conversions ;

b. The Apparent Activation Energies obtained were 55.60 and 91.71 $\mathrm{kJ} / \mathrm{mol}$, for $100 \% \mathrm{CO}$ and $50 \% \mathrm{CO}-50 \% \mathrm{CO}_{2}$, and 54.74 and 100.51 $\mathrm{kJ} / \mathrm{mol}$ respectively.

c. It is notably that maximum reduction percentagem achieved by EAFD reduction through CO pure was of circa of $100 \%$ at $1273 \mathrm{~K}$ and 80.75 minutes.

$\checkmark$ The maximum zinc ferrite synthetic reductions indexes obtained in these experiments were $85 \%$, for $100 \% \mathrm{CO}$ at $1373 \mathrm{~K}$, in $105 \mathrm{~min}$, and $52 \%$, for $50 \%$ CO at $1373 \mathrm{~K}$, and $100 \%$, for $100 \%$ CO at $1373 \mathrm{~K}$, in $105 \mathrm{~min}$, and approximately $60 \%$, for $50 \% \mathrm{CO}$ at $1373 \mathrm{~K}$ elapsed $105 \mathrm{~min}$, in the case of EAFD reduction.

$\checkmark$ To determinate a comprehensive kinetic equation for the reduction process of zinc ferrite by $\mathrm{CO}$, the study under other gaseous compositions is being carried out. The results will permit a better decision making actions aiming at the reclaim of the zinc element from steelmaking dusts. 


\section{Acknowledgements}

The authors wish to thank the Graduate Teaching Personnel Supporting Council Capes and the National Research Council - CNPq, as well as Prof Guillermo S. Naranjo and Eng Raimundo N. Rodrigues Filho.

\section{REFERENCES}

1 HSI-KUEI CHEN; CHING-YI YANG, 2001. A study on the preparation of zinc ferrite. Scandinavian Journal of Metallurgy, No.30, 2001.

2 JYH-JEN LEE, CHUN-I LIN, AND HSI-KUEI CHEN, 2001. Carbothermal reduction of zinc ferrite. Metallurgical and Materials Transactions B. Volume 32B, December 2001, p.1033-1040, 2001.

3 BID S.; PRADHAN S. K. Preparation of zinc ferrite by high-energy ball-milling and microestruture characterization by Rietveld's analysis. Materials Chemistry and Physics No.82, p.27-37 2003.

4 GÓMEZ-MARROQUÍN, M. C., D'ABREU, J. C., KOHLER, H. M., 2014. "Cinética da Redução de Ferrita de Zinco e de Poeiras de Aciaria Elétrica por Misturas $\mathrm{CO}-\mathrm{CO}_{2}$ " presented during the $69^{\circ}$ CONGRESSO ANUAL DA ABM on July $21^{\text {st }}$ to $25^{\text {th }}, 2014$ in São Paulo, SP-Brazil.

5 GÓMEZ-MARROQUÍN, M. C. \& D'ABREU, J. C., 2012. Kinetics Reduction of Zinc Ferrite contained in EAFD, by pure $\mathrm{CO}$ and $\mathrm{CO}-\mathrm{CO}_{2}$ Gas Mixtures, presented to the $6^{\text {th }}$ International Congress on the Science and Technology of Ironmaking - ICSTI / $42^{\text {nd }}$ ABM Ironmaking Seminar \& $13^{\text {th }}$ ABM Iron Ore Symposium, from $14^{\text {th }}$ to $18^{\text {th }}$ October 2012 in Rio de Janeiro - RJ - Brazil. http://www.gbv.de/dms/tib-ubhannover/767806328.pdf

6 GÓMEZ-MARROQUÍN, M. C.; D'ABREU, J. C., 2011. "Reducción de Polvos de Aceria por Mezclas CO - CO2, presented to the Operators Encounter of 30 PERUMIN CONVENCION MINERA. Theme: Mining Research from $12^{\text {th }}$ to $18^{\text {th }}$ September 2011 in Arequipa Peru.

7 GÓMEZ-MARROQUÍN, M. C.; D'ABREU, J. C., 2010. "Cinetica de Reducción de Ferrita de Cinc presente en los Polvos de Acería por la Mezcla $\mathrm{CO}-\mathrm{CO}_{2}$ ", presented to the $1^{\text {st }}$ International Congress of Extractive Metallurgy and $5^{\text {th }}$ International Congress of Transformation Metallurgy, that took place between $24^{\text {th }}$ and $27^{\text {th }}$ November 2010 in Tacna -PERU. Anals of event. V. 1, p. 206-209.

8 GÓMEZ-MARROQUÍN MERY CECILIA, 2008. Characterization and Zinc Ferrite contained into Steelmaking Dusts Reduction, by $\mathrm{CO}-\mathrm{CO}_{2}$ Gás Mixtures. Doctoral Thesis Dissertation - Department of Science of the Materials and Metallurgy, Papal Catholic University of Rio de Janeiro. DCMM - PUC-Rio, 2008, 230 p. Advisor: Prof. D'Abreu José Carlos.

9 GÓMEZ-MARROQUÍN MERY CECILIA, 2004. Contribution to the Study of the Formation and Reduction of Zinc Ferrite. Dissertation of MSc. Dissertation - Department of Science of the Materials and Metallurgy, Papal Catholic University of Rio de Janeiro. DCMM - PUC-Rio, 2004. 173p. Advisor: Prof. D’Abreu José Carlos.

10 HUI-NING ZHANG; JIAN-LI LI; AN-JUN XU; QI-XING YANG; DONG-FENG HE; NAI-YUAN TIAN, 2014. Carbothermic Reduction of Zinc and Iron Oxides in Electric Arc Furnace Dust. Journal of Iron and Steel Research, International 2014, 21(4): p. 427-432.

11 TONG, FUI LEE, 2001. Reduction mechanisms and behaviour of Zinc Ferrite-Part 1: pure $\mathrm{Zn} \mathrm{Fe} \mathrm{O}_{4}$. Received by the Institution of Mining and Metallurgy on 21 February, 2001; Paper published in Trans. Instn Min. Metall. (Sect. C: Mineral Processes. Extractive Metallurgy), 110, January-April 2001. 